\title{
Discurso em Comemoração do Sesquicentenário da Fundação dos Cursos Jurídicos no Brasil.
}

\author{
Gentil do Carmo Pinto \\ Presidente do Tribunal de Justiça do Estado
}

No reencontro de antigos alunos, irmanados pelo batismo de calouro, prosternamo-nos, Academia, sob o pálio bendito de teu templo, para a prece sesquicentenária.

Centúria e meia de fastos e tradições ressoam de teu solo sacrossanto, trincheira da consciência jurídica, cidadela de idealismo e cultura, vanguarda de aspirações liberais, baluarte de patriotismo.

O facho sagrado que ergueste da luta pelo direito transmitiu-se de geração a geração na maratona da tutela do indivídu.o e da sociedade.

O texto normativo, a metafísica, a política, a dialética, a hermenêutica, a jurisprudência, a cadência poética vibraram e pulsam em tuas arcadas, povoando teus muros na confraternização das tertúlias acadêmicas.

o chamado que as aulas anuncia, sucedendo ao dobre do Mosteiro, fez-se convocação cívica, para a Guerra do Paraguai, a Abolição, a República, o Federalismo, a campanha civilista, a epopéia de 32 , a redemocratização, os heróis de Monte Castelo, o Estado de Direito.

Dínamo de inteligência, iluminaste os caminhos da Nação com estadistas proeminentes e figuras exponenciais da ciência jurídica, da diplomacia, da oratória e das letras.

Catedral do Direito, preservas a mística do velho Cláustro, entronizando a lei no altar do culto à dignidade humana.

* Discurso proferido na Sessão Solene de Encerramento das festividades comemorativas do Sesquicentenário da Fundação dos Cursos Jurídicos no Brasil, realizada no Salão Nobre da Faculdade de Direito a 11 de agosto de 1977. 
A juventude fiel que congregas, tendo o código por breviário, renova com vigor no teu pátio o compassar das meditações do Convento.

$\mathrm{Na}$ liturgia das classes conferes a comunhão do pão do espírito que se multiplica; ensinas o catecismo da igualdade jurídica; entoas a litania do bem comum; incensas o sacrário da justiça; cantas o salmo do conteúdo ético da vida; difundes o evangelho da preservação dos valores universais que asseguram os direitos humanos; administras o sacramento da liberdade; pregas a democracia pelo missal da Constituição, desfiando o rosário das garantias individuais.

Fraternidade franciscana, retiras de teu burel a semente fecunda de teu credo, estendendo a bênção de teus beirais por homens e geografias.

No teu jus, apostolado que a tudo rege da concepção ao túmulo, projetas a dimensão global dos temas comunitários.

Teus passos sublinham e sublimam nossa história.

Santificada seja tua obra cheia de frutos.

Pela cruzada - que lideras - da inalienabilidade e perpetuidade das instituições jurídicas, - nós te rendemos graças.

Pelo milagre do renascer dos corações que sagras cavaleiros do direito, - nós te rendemos graças.

Pela missão cultural e redentora que por século e meio exercitas, - nós te rendemos graças.

Pela mensagem de fé que nos traz teu passado de glórias, — nós te rendemos graças.

Universo do espírito; tua casa é santuário e continente, teu largo é livre território e firmamento.

Fulguras e viverás na voz de teus filhos fanal -

- pendão, centelha, brado, horizonte, estrela, verdade,

Escola de liberdade

Santa Academia

Faculdade imortal. 